\title{
Depoliticizing Democracy
}

\section{PHILIP PETTIT*}

\begin{abstract}
It is now widely accepted as an ideal that democracy should be as deliberative as possible. Democracy should not involve a tussle between different interest groups or lobbies in which the numbers matter more than the arguments. And it should not be a system in which the only arguments that matter are those that voters conduct in an attempt to determine where their private or sectional advantage lies. Democracy, it is said, should promote public deliberation among citizens and authorities as to what does best for the society as a whole and should elicit decision-making on that basis. But the ideal of deliberative democracy has two components-the deliberative and the democratic - and often they pull apart. In this paper I look in the first section at a series of problems that arise on the deliberative front, arguing that their resolution requires various degrees of depoliticization. And then I ask in the second whether the depoliticizing responses that those problems require are antithetical to the ideal of democracy. I argue that they are not in tension with the ideal, if that ideal is cast in the relatively revisionary, two-dimensional form that I favour. ${ }^{1}$
\end{abstract}

\section{Deliberation Requires Depoliticization}

\subsection{Electoral Interests and Deliberation}

I assume that the prospect of plebiscitary government is infeasible and indeed that it would be wholly inimical to the cause of deliberation, so that democratic government is inevitably representative government (see Pettit 2003). What are the prospects for deliberative government, then, if control is left wholly or mainly to representatives in parliament, or to a government with a parliamentary majority, or to an elected administration? A number of problems argue for depoliticizing moves.

A first problem arises from the fact that even if elected officials have the interests of the community as a whole at heart they are still bound to be

* My thanks to Jerry Masor for helpful comments and recommemdations. Among other things, he drew my attention to a piece that fits broadly with the spirit of my own paper: Seidenfeld 1992.

1 The paper draws freely on ideas presented in different forms elsewhere. See Pettit 1997, 1999, 2000, 2001a, 2001b, 2002, 2003. The first part of this paper reproduces, with some small variations, a section of Pettit 2001a. 
responsive to their own interest, or their party's interest, in being re-elected. If electoral interests of this kind are engaged in some of the policy-making decisions over which representatives have political control, then they cannot be reliably expected to decide those issues by reference just to considerations of the common good. Nemo judex in sua causa. No one to be judge in his or her own cause. The principle applies as much to those in politically elective office as it does to those in judicial and related areas.

One obvious area in which the principle applies is that of deciding on electoral boundaries and the number of representatives to be assigned to each area. And here many countries have taken note of the problem under discussion and have depoliticized the decisions in question. Electoral commissions may be subject to the ultimate control of parliament-parliament may have hands-off control, as it were-but they are designed precisely to meet the sort of problem we are dealing with. They take the decisions away from the direct influence of representatives-thereby, incidentally, relieving representatives of the need to fight many fruitless battles-and they are forced to make the decisions under conditions where considerations of the common good, and only such considerations, are very likely to rule. Their decisions have to be justified by strict guidelines that have had to be accepted by those on all sides of politics, and if the commissions fail to present a satisfactory justification - to give democratically persuasive reasons for their decisionsthen they will certainly face a public and political outcry.

There are a number of areas of decision-making where democracies have depoliticized decisions, for fear of allowing electoral interests to dictate what government does; the outstanding example is interest-rate policy and exchange-rate policy, where relatively autonomous central banks are routinely given charge. But there are novel areas too where electoral interests are likely to militate against the deliberative quality of democratic decisionmaking, depriving considerations of the common good of the weight they are properly given.

Here I mention one example that is particularly striking, since it comes up day after day in national and state politics. The example is the way that governments privilege, or at least are assumed to privilege, marginal seats in the exercise of various forms of discretion. If a government faces a decision that will benefit one constituency or another, and if it has a powerful party-related interest for benefiting one of them, then there is little or no hope that it will be guided just by considerations of the common good. Or at least that will be so if it enjoys political control over the decision. Once again, then, the ideal of deliberative democracy will be compromised.

Just as electoral commissions depoliticize boundary and related decisions, and allow them to be made in a deliberatively democratic way, so the cause of deliberation would argue for introducing a similar system that would guard against privileging marginal seats. The commission would operate at arm's length from parliament and government, and might be required to 
review and approve any proposed government expenditures-at least expenditures above a certain amount- that benefit constituencies which are marginal in a stipulated degree. I cannot speak in this context to how exactly such a commission might be constituted but I think that anyone who takes the ideal of deliberative democracy seriously must have an interest in investigating the feasibility of such a depoliticizing institution.

\subsection{Popular Passion and Deliberation}

There are other less direct ways in which electoral interests can play a role in undermining the deliberative element in the deliberative democratic ideal and the remaining three problems illustrate them. Electoral interests raise problems so far as they ensure that rather than letting the common good crystallize and rule, as deliberative democracy would require, they invest power in other sources of influence: popular passion, aspirational morality and sectional interest.

The problem with popular passion can be illustrated in the area of criminal sentencing policy. ${ }^{2}$ Imagine that a certain pattern of policing and sanctioning is working quite well across a broad range of criminal activity, and working in such a way that imprisonment is not often imposed; community service is the sanction of first resort. And think now of how the pursuit of electoral advantage might lead to a politics that generates a much more severe and costly rate of imprisonment, and do so without achieving any compensatory advantage: might do so, indeed, while allowing the level of crime to rise.

No matter how well the criminal system is working in a polity, there is always going to be a case, sooner or later, where a convicted offender who received a relatively light sentence, say community service, would not have committed a later crime, had he actually been put in prison. The later crime may involve some horrific event, like an attack on a child or a brutal rape or an armed assault. And if it does, then the politician who cares to make a big noise about this event can be sure of whipping up public passion around the issue and, given that such noise sells newspapers and attracts television viewers, can be assured of getting support from the media. Thus we can easily see why such a politician or a party, particularly one out of government, can have political advantage to make from denouncing the existing, relatively lenient pattern of sentencing, calling for heavier sentences, even perhaps for capital punishment. They can activate a politics of passion in which they appear as the only individual or the only group really concerned about the sort of horrible crime in question. They can call into existence what Montesquieu called a tyranny of the avengers, letting loose a rule of kneejerk emotional politics that works systematically against the common good.

${ }^{2}$ For a more detailed treatment, see Pettit 2002. The analysis there draws on dynamics first identified in MacDonagh 1977. See too Greenberg 2002.

(c) Blackwell Publishing Ltd 2004. 
This phenomenon has marked politics all over the western world in the last decade or two. A well known illustration of this effect is provided by the second public debate between the candidates in the 1988 campaign for the presidency of the United States. As governor of Massachusetts, Michael Dukakis had maintained a regime of comparatively lighter criminal sentencing than was common in other States. Despite the fact that the crime figures for Massachusetts compared favourably with those elsewhere in the U.S., he came under severe criticism-and arguably lost the initiative in the election-when his opponent, George Bush, drew attention to a particular, heinous crime that the more lenient measures had made possible; this was committed by Willy Horton, a prisoner on furlough under a Massachusetts State program. ${ }^{3}$ Dukakis was readily presented as soft on crime, and became an object lesson to politicians the world over. The message was: Never allow yourself to be upstaged in the expression of popular horror at criminal acts; always stay at the front of the pack that bays for revenge. ${ }^{4}$

How might this sort of affront to deliberative democracy be rectified? Once again, the only hope would seem to lie in depoliticization. It would require parliament to appoint a commission representative of relevant bodies of expertise and opinion, as well as of the people as a whole, to oversee criminal sentencing. It would give it a brief to establish sentencing guidelines, to monitor any changes made in existing practice, and to judge on those changes by the aggregate benefits and costs to the community. Parliament might well retain ultimate control over such a commission but by putting its control at arm's length in such a manner-by retaining only the hands-off sort of control that parliaments have over electoral commissionsit would serve the cause of deliberative democracy rather better than does the status quo.

\subsection{Aspirational Morality and Deliberation}

So much for a case where passion rules in place of the considerations of the common good that deliberative democracy would prioritise. A second sort of example illustrates the way in which people's aspirational moralityempowered by electoral interests-may rule in place of such considerations.

Imagine that prostitution is legalised within quite specific limits in a community, with brothels being subject to strict regulation, and street soliciting prohibited. Most people in the community will think that prostitution is morally undesirable-it offends against a range of aspirational ideals, religious and otherwise- but the fact is, let us assume, that it serves the common good better to have a legalised, regulated system of prostitution rather than allowing it operate in the criminal underworld. In such an

\footnotetext{
${ }^{3}$ On the force of vivid examples in argument see Tversky and Kahneman 1982.

${ }^{4}$ For background see http://www.kennesaw.edu/pols/3380/pres/1988.html.
} 
underworld, prostitutes would have no protection from the law against exploitation and abuse, and they would have less opportunity and incentive to guard against sexual diseases.

As in the previous example, it is easy to see how in such a situation a politician or party might find political advantage in denouncing the government for allowing prostitution to continue in the society, thereby giving it a sort of recognition and acceptance. The individual or party might easily appeal to people's perfectly reasonable ideals, challenging them to say whether or not they countenance prostitution and eliciting a fair measure of support among the large majority who don't. They can reasonably hope to activate a politics of moralism, in which the options are presented in a false, dichotomous light: denounce prostitution or give it recognition. In this light, there is no attention given to the possibility of denouncing prostitution at a moral level, while recognising that it is impossible to stamp it out by legal and political means and that it is better to have a legalised, regulated system rather than moving in a prohibitionist direction. Were a politician or party to succeed in getting this sort of issue considered in a referendum, or made into a central electoral question, then they might well hope to win. Certainly they might hope to attract many voters to their side.

In the previous example, politicians might have hoped to attract voters to their side through focussing on a couple of horrific abuses, relying on vivid examples to arouse people's passions and to move them more than any number of aggregate statistics. In this example they can hope to attract voters to their side through invoking widely held and quite intelligible ideals rather than passions as such. When people are asked to vote on the legalisation of something like prostitution, they are not individually asked to decide whether there should be a regulated or a prohibitionist system; were they asked that question, then of course the thing to do would be to consider the overall consequences of each arrangement and make a rational choice between the two. They are asked to give their opinion of the options at stake, and that question has the cast of an inquiry after their moral stand, so that many people will respond with a negative judgment on prostitution. ${ }^{5}$

As people may be expected to respond in this way to prostitution, of course, so in general we may expect them to respond in like manner to all of those questions in public life where personal, aspirational ideals are intimately engaged. The best current example of another such question, of course, arises in the area of addictive drugs. Those politicians who take the high moral ground on that issue can do so in the assurance that this is good politics: good politics but not necessarily good government.

As with the cases involving the rule of people's passions, there is very good reason in cases of the moralistic kind to consider the formation of a depoliticized forum, at arm's length from parliament, which can offer

${ }^{5}$ For an identification and explanation of the problem, see Brennan and Lomasky 1993.

(c) Blackwell Publishing Ltd 2004. 
guidelines on what sorts of activities amongst those offending against most people's moral ideals ought to be legalised; and in the case of legalisation, on how they ought to be regulated. This body could represent different sectors of popular opinion and professional expertise and would be able to take a long-term view, informed by sustained monitoring, of the costs and benefits of different overtures. While subject to the ultimate control of parliament, it would surely give a boost to the rule of deliberative democracy in public life.

\subsection{Sectional Interest and Deliberation}

A third and last example of how electoral interests can indirectly jeopardise the ideal of deliberative democracy arises where politicians actively canvass and obtain the reactions of people to various government proposals and then defend the position they take on the basis of which lobby represents itself most effectively. The problem here, familiar to students of public choice, is that if an overture advantages a large number of people in a small measure but disadvantages a small number of people in a large measure, then the disadvantaged will have both a stronger incentive and a better opportunity to organise themselves into an effective lobby (Olson 1965). The problem bedevils discussion of a wide number of public issues, ranging from where to establish main roads, to where to build prisons and public utilities, to where to situate airports, and the like. It reduces the operation of democracy on most such questions to a process of overblown rhetoric and mutual abuse, in which there is nothing remotely resembling deliberation about the demands of the common good. It is not now popular passion or aspirational morality that undermines the rule of reason but good, oldfashioned self-interest.

As the other problems suggest that we should look to the possibility of depoliticizing the area of decision-making in question, thus allowing democracy to remain deliberative, so this sort of problem naturally invites a similar response. And there is a depoliticizing proposal actively in circulation, which has now been trialled in a number of countries, whereby the difficulty might be overcome. James Fishkin of the University of Texas introduced the idea, which he describes as that of a deliberative opinion poll (Fishkin 1997). ${ }^{6}$ What it involves is taking a random, statistical sample of the population-perhaps a group of about three hundred-and then bringing them together for a period of discussion and information-gathering before polling their opinions. Such a deliberative opinion poll would surely serve deliberative democracy well in many of the sorts of areas mentioned in this third category, for it would give those in government an excellent sense of

\footnotetext{
${ }^{6}$ Related institutions include the idea of the citizen jury and, at least if it is used appropriately, the focus group.
} 
the balance of informed opinion in the society as a whole. It would enable political debate to operate at a significant remove from the intensity of lobby politics.

\section{Depoliticization Is Consistent with Democracy}

The problems rehearsed in the first part of this paper are all of a familiar kind and in going through them I have probably been labouring the obvious. Not everyone will agree that the line required in each case for solving those problems-for giving deliberation a central place in government-is one of depoliticization: one of reducing the hands-on power of the people's elected representatives. But I hope that many will agree, on the basis of the examples provided, that such depoliticization often makes sense. And so the question arises as to whether the depoliticization required is inimical to the ideal of democracy. I shall argue that it is not. More specifically, I shall argue that it is not inimical to democracy, under one of two saliently different interpretations of the ideal.

\subsection{Two Views of the Ideal of Democracy}

Perhaps the most familiar conception of the role of democracy is that it serves as the means whereby a people as a whole asserts its collective will: its own will as distinct from the will of a dictator or an elite or a foreign power. On this conception, democracy is an ideal for a people that parallels the ideal of autonomy for an individual. The democratic people is an autonomous people: a people which gives laws to itself, rather than have them emanate from an alien or heteronomous source.

If democracy is understood in this way, then only those aspects of popular control will be relevant to democratic government that enable the people as a whole to assert itself. The primary means of collective self-assertion will be the plebiscite or referendum. The secondary will be the electoral choice of parliamentary representatives and an associated administration on the basis of their policy program, and the maintenance of electoral control by the requirement of seeking re-election, debating in parliament with opposition representatives, and dealing with public opinion.

But there is an alternative conception of the role of democracy, which also surfaces from time to time in popular and philosophical discussions. According to this conception, the people should control government democratically because that is the only mode of control under which those reasons can be expected to guide government that are recognized in common deliberation as the valuations relevant to determining public policy. This conception represents democracy, not as a regime for the expression of the collective will, but rather as a dispensation for the empowerment of public valuation. 
Let people debate public policy, as democratic electorates and parliaments routinely do, and certain considerations will inevitably emerge as those that everyone countenances as relevant, that everyone expects everyone to countenance as relevant, that everyone expects everyone to expect everyone to countenance as relevant, and so on. ${ }^{7}$ In cases where people do not agree on the detailed weightings that such different considerations should carrymost cases, perhaps-common considerations of the kind envisaged may argue for the resolution of public issues by particular procedures: say, by reference to majority voting among representatives, or by referral to a presumptively impartial committee or umpire, or even by lot.

Considerations that would not pass muster in public debate about what government should do include self-seeking observations to the effect that such and such an initiative would give one section of the population an advantage over others, as well as expressions of what is required by an ideal or cause that is not shared by all. The considerations that are likely to be accepted as relevant on all sides come in two broad categories. First, neutral considerations that concern the general prosperity of the society, or its efficacy in attaining agreed ends, or the assurance available to each that no other members enjoy any particular privilege, and so on. And second, those more personal complaints that members of different groups may raise against various proposals and that secure acceptance as reasonable: "That's going to make life difficult for those of us who are poor/who belong to an ethnic minority/who live in rural areas ..."

So far as deliberation filters out certain considerations as those that are commonly countenanced in the society, the role of democracy may be cast as one of ensuring that government is conducted as those common reasons or valuations dictate, and only as they-at least in ultimate principledictate. I refer to the reasons or valuations empowered in this way as public. They are public both in the sense of being valuations that determine how public issues should be resolved-what public decisions should be taken or what mode of public decision-making should be used-and in the sense of being valuations that are endorsed by the public: that is, endorsed in common among members of the public.

If democracy is meant to be a system whereby the collective will of the people rules, via representative government, then the depoliticization required by deliberation must be seen as inimical to the democratic ideal. ${ }^{8}$ The considerations raised in the first part of the paper show that if deliberation is to predominate, then the power of those representatives must be passed on in various areas to appointed boards and officials. But so far as power is given to the unelected in this manner, the democratic empowerment

\footnotetext{
7 "And so on" may be glossed to mean: and for any higher-order question in this sequence, people are disposed to form similar, confirmatory expectations.

${ }^{8}$ Thus, see the proposal to eschew the use of the term "democracy" defended in Rubin 2001.
} 
of the collective will is inevitably compromised. Those attached to this image of democracy cannot be relaxed about depoliticization, then. They must think that it is undemocratic and they must recognize that the demands of deliberation-assuming that deliberation requires depoliticization-are in conflict with the demands of democracy. They must see deliberative democracy as an impossible, or at least dubiously coherent ideal.

Things look very different, however, under the alternative conception of the democratic ideal. In the remainder of this paper I offer a more detailed account of that conception and I try to show how it makes room for a significant degree of depoliticization.

I do not offer any defence here of the conception of democracy as the empowerment of public valuation rather than collective will but two remarks in its favour are worth mentioning. The first is that there is no metaphysical difficulty about the idea of common valuation that besets, notoriously, the idea of collective will. ${ }^{9}$ And the second is that there is considerable normative attraction in the idea of common valuation dictating what happens in government; this is encoded in the traditional, republican idea of empowering the common good (Pettit 2004).

\subsection{The Two-dimensional Ideal of Democracy}

If democracy is conceived as a system for empowering the public reasons recognized among a people-their common valuations - rather than the will of that people considered as a collective agent, then two dimensions of control are going to be relevant in the determination of policy. It is going to be important that public valuations rule, in the sense that the initiatives they support tend to be reliably identified and implemented; they are not overlooked. And it is going to be important that only public valuations rule, in the sense that whatever initiatives are adopted are justifiable by reasons that are commonly recognized as relevant in the public arena. They may be directly justifiable by reference to those reasons or they may be adopted under procedures that are justifiable in that way.

The first requirement, in an established phrase, is that institutions be designed so as to avoid false negatives: that is, failures to perceive options that public valuation would support. The second requirement is that institutions be designed so as to avoid false positives: that is, misperceptions or misrepresentations of what public valuation supports; in particular, the misidentification of policies that are prompted only by factional or sectional interest as initiatives that enjoy the support of such valuation.

Electoral institutions are the obvious means whereby the first of these desiderata can be promoted. Such institutions will give people the power of

\footnotetext{
${ }^{9}$ The core difficulty with the notion of collective will is that it presupposes collective agency, and that the existence conditions for a collective agent are too demanding for a large-scale populace or electorate to satisfy. See List and Pettit 2002.
} 
choosing representatives. In seeking election, those representatives will compete in proposing initiatives, and so compete in the search for initiatives that public reasons might support. And, just as importantly, they will be disciplined by considerations of re-election or public opinion or parliamentary challenge to stick to whatever programs the people endorse. Electoral competition and discipline of this kind ought to ensure that the candidates and parties involved will have a powerful initiative to seek out policies that are supported by public valuation - these ought to be electorally attractive, after all-and to implement them in government; it sought to guard against false negatives. Or at least it ought to do so in the degree to which the competition is not distorted, as it routinely is, by the pressures associated with campaign financing, lobby-group pressure, and so on.

But how is the second desideratum to be promoted, with institutions guarding against false positives? False positives are likely to materialize under electoral institutions in one of two ways. Either in virtue of a tyranny of the majority, as when majority interests surface in elections and carry the day against what commonly endorsed reasons would support. Or in virtue of a tyranny of the elite, as when those who are insiders by dint of office or connection or wealth are able to hide what is going on in the corridors of power and to intrude their own interests into the determination of policy. If electoral institutions are the obvious means of guarding against false negatives in government, then what institutions can serve to guard against false positives?

What is needed, I suggest, are institutions that are broadly contestatory in character. Those individuals or groupings who believe that power is not being exercised in the common interest - not being guided by public valuation-must be in a position to challenge a government decision, arguing with some prospect of success that it is not well supported by the public reasons recognised in the community and should therefore be amended or rejected. The people must be individually enabled to act as editors of the laws and policies that the representatives author-and author in their collective name.

The editorial metaphor helps to highlight the contestatory power that the people can be given. Consider the ways in which the editors of a newspaper will exercise control over would-be authors. First of all, they will inevitably have virtual control of every piece published, even if they do not causally intervene in the authorship; the fact that it was possible for them to intervene in the event of an article not passing muster means that they have to assume responsibility for it, equally with the author. ${ }^{10}$ Second, the editors will have inhibitory control of many pieces they publish, so far as the authors anticipate their reactions and self-censor in the attempt to secure smooth publication. And third, the editors may have interventional control

${ }^{10}$ I introduced this distinction, in a rather different context, in Pettit 1995. 
so far as they take exception to a piece and reject it or amend it or enter into negotiation with the author as to how it should be revised.

These three forms of control are likely to be enjoyed by ordinary people so far as there are contestatory institutions available for them to make their voice heard. They will have virtual control over government laws and decrees even in the absence of any intervention, because the fact that they do not contest those decisions will be partly responsible for the shape the decisions assume. They will have inhibitory control over government so far as the authorities are wary of activating any protest or appeal against their actions. And of course they will have interventional control so far as they actually do contest decisions of government and have an effect upon them. ${ }^{11}$

Not only does the editorial metaphor point us in this way to three different aspects of contestatory control. It also suggests two modes in which the interventional variety of contestatory control may be implemented and the other varieties indirectly shaped. Journals and newspapers will facilitate contestation by enabling their editors to contest submissions they don't like. But they will also make arrangements to ease the burden of such one-byone contestation. They will adopt arrangements for forestalling as well as facilitating contestation, setting out guidelines that authors should meet in their submissions, requiring authors to consult with editors in advance about matters of style and argument, and so on.

It is clear, in parallel, that there is ample democratic room for making arrangements that forestall, as well as arrangements that facilitate, contestation. Forestalling initiatives will involve putting in place constraints that are designed to reduce the burden of contestation, making it less likely that government behaves in a manner that people will want to question and change. They will introduce regulative arrangements that protect against those sorts of abuses that flout the demands of public reason and would reliably generate successful contestation.

\subsection{Depoliticization under the Two-dimensional Ideal}

Depoliticization is an inherent part of a two-dimensional democracy. This is true, in the first place, of the arrangements needed for facilitating contestation. The bodies and officials responsible for hearing such contestationscourts, tribunals, ombudsmen, and the like-will have to be distinct from

\footnotetext{
${ }^{11}$ Notice that only the third of these forms of control involves direct causal efficacy. Control in the other cases materializes so far as what government does is counterfactually dependent on the views of the people-were those views other than they are, then government action would differ accordingly - but this counterfactual dependency does not require active causal influence. It is important to recognise that democratic control need not involve causal control if the full potential of democracy is to be appreciated. The point is only rarely noticed, however; one example is in Harrison 1993.
} 
the elected forums and personnel that gave rise to the laws and decrees that are being contested. Otherwise there would be little or no hope of having a process that genuinely tested those laws and decrees for the extent to which they answer to public valuation. Certainly there would be no hope of having a process that would command the confidence of those making the contestation.

But depoliticization is even more obviously a part of the institutions necessary for forestalling contestation, reducing the contestatory burden. These institutions are likely to come in three varieties: constitutional constraints, consultative procedures and arm's-length appointments. And all of those devices involve depoliticization of the kind discussed in the first section.

Constitutional constraints will put in place sanctions against governmental behaviour that would certainly be contested, were it to materialise, and contested with good, palpable reason. This mode of regulation pre-empts the reasonable contestation that such behaviour would elicit, and renders it unnecessary. Constitutional constraints will have a genuinely inhibiting effect on government, however, only so far as there is a constitutional court-whether in the European or American mould-that operates independently and impartially. And if it is to be independent and impartialcertainly if it is to be believed to be such-then that sort of court must operate away from the control of politics.

Procedures for consultation also promise to reduce contestatory burdens. These procedures would require governments in various areas of policy to put out their proposals for public discussion and feedback. They would ease the contestatory burden in a democratic society by giving people an ex ante opportunity to raise questions about proposed laws and decrees, and perhaps to help shape them, rather than restricting contestation to an ex post appellate form. These too will require depoliticization, being reliable only insofar as governments are forced to do the job impartially, rather than seeking out the opinions of their friends; they may require, for example, the sort of deliberative opinion poll mentioned earlier.

Depoliticization is likely to be at its most intense, however, in arrangements for officials and boards that operate at arm's-length from elected representatives. These will create various roles or bodies to which people are appointed by an established procedure, and then allocate to them decisions that it would be dangerous to leave in the hands of representatives: dangerous, because of the temptations that elected representatives would have to let their choices be dictated by inappropriate considerations. In particular, it will involve this in areas where such appointments are not already required for making contestation possible or for making constitutional constraints and consultative procedures effective. I am thinking of appointments in roles like those of the auditor or statistician or equality commissioner or to bodies like that of the census bureau. 


\subsection{Conclusion}

We saw in the first part of this paper that if deliberation is really supposed to rule in public life, then there is no option but to depoliticize public decisions in various ways. Does this mean that the cause of public deliberation tells against the ideal of democracy? Yes, if democracy just means empowering the collective will. No, so we have argued, if it means empowering public valuation: more specifically, empowering those considerations that people countenance as relevant to decisions on public policy. The ideal of a deliberative democracy, then, is not incoherent. But it is an ideal with a certain paradoxical aspect. As war is too important to be left in the hands of the generals, democracy-deliberative democracy-is too important to be left in the hands of the politicians. No democratization without depoliticization.

Princeton University Department of Politics

Corwin Hall 034

Princeton, NJ 08544 U.S.A.

E-mail:ppettit@princeton.edu

\section{References}

Brennan, G., and L. Lomasky. 1993. Democracy and Decision: The Pure Theory of Electoral Preference. Oxford: Oxford University Press.

Fishkin, J. S. 1997. The Voice of the People: Public Opinion and Democracy. New Haven, CT: Yale University Press.

Greenberg, D. F. 2002. Striking Out in Democracy. Punishment and Society 4: 237-52. Harrison, R. 1993. Democracy. London: Routledge.

List, C., and P. Pettit. 2002. The Aggregation of Sets of Judgments: An Impossibility Result. Economics and Philosophy 18: 89-110.

MacDonagh, O. 1977. Early Victorian Government. London: Weidenfeld and Nicolson.

Olson, M. 1965. The Logic of Collective Action. Cambridge, MA: Harvard University Press.

Pettit, P. 1995. The Virtual Reality of Homo Economicus. Monist 78: 308-29.

. 1997. Republicanism: A Theory of Freedom and Government. Oxford: Oxford University Press.

- 1999. Republican Liberty, Contestatory Democracy. In Democracy's Value. Ed. C. Hacker-Cordon and I. Shapiro. Cambridge, MA: Cambridge University Press. 2000. Democracy, Electoral and Contestatory. Nomos 42: 105-44.

. 2001a. Deliberative Democracy and the Case for Depoliticizing Government. University of New South Wales Law Journal 24: 724-36.

- 2001b. A Theory of Freedom: from the Psychology to the Politics of Agency. Cambridge, MA: Oxford University Press. Press. 
2002b. Is Criminal Justice Politically Feasible? Buffalo Criminal Law Review 5: 101-24.

2003. Deliberative Democracy, the Discursive Dilemma, and Republican Theory. In Philosophy, Politics and Society. Vol 7: Debating Deliberative Democracy. Ed. J. Fishkin and P. Laslett, 138-62. Cambridge, MA: Cambridge University Press. . Forthcoming. The Common Good. In Justice and Democracy: Essays for Brian Barry. Ed. K. Dowding, R. E. Goodin and C. Pateman. Cambridge, MA: Cambridge University Press.

Rubin, E. L. 2001. Getting Past Democracy. University of Pennsylvania Law Review 149: 711-92.

Seidenfeld, M. 1992. A Civic Republican Justification for the Bureaucratic State. Harvard Law Review 105: 1511-76.

Tversky, A., and D. Kahneman. 1982. Judgments of and by Representativeness. In Judgment Under Uncertainty: Heuristics and Biases. Ed. D. Kahneman, P. Slovic and A. Tversky. 84-98 Cambridge, MA: Cambridge University Press. 
